\title{
O niektórych przypadkach fali orograficznej w Beskidzie Niskim oraz jej znaczeniu dla szybownictwa
}

\author{
About certain cases of a mountain lee wave in Beskid Niski Mts. \\ and its significance for the gliding
}

\begin{abstract}
JAKUB SZMYD
Instytut Geografii i Przestrzennego Zagospodarowania im. S. Leszczyckiego PAN, 00-818 Warszawa, ul. Twarda 51/55, j.szmyd@twarda.pan.pl
\end{abstract}

\begin{abstract}
Zarys treści. W artykule scharakteryzowano falę orograficzną w Beskidzie Niskim. Na podstawie dokumentacji szybowcowych akcji lotów falowych Aeroklubu Podkarpackiego w Krośnie stwierdzono, że zjawisko najczęściej występuje w półroczu chłodnym (zwłaszcza w listopadzie), a jego rozwojowi sprzyja adwekcja powietrza z południa i południowego zachodu, bardziej sytuacje cyklonalne niż antycyklonalne. Wykazano, że minimalna prędkość wiatru niezbędna do wzbudzenia fali wynosi $7 \mathrm{~m} \cdot \mathrm{s}^{-1}$, natomiast do jej powstania nie jest konieczne występowanie stabilnych warunków cyrkulacyjnych. W pracy przedstawiono różnice między własnościami fali orograficznej w Beskidzie Niskim i nad pozostałymi pasmami głównymi Karpat Polskich, zwłaszcza w Tatrach. Uzyskane wnioski rozpatrzono w kontekście praktycznego znaczenia dla szybownictwa.
\end{abstract}

Słowa kluczowe: fala orograficzna, meteorologia lotnicza, szybownictwo, Beskid Niski, Karpaty.

\section{Wprowadzenie}

Fala orograficzna jest zjawiskiem atmosferycznym występującym nad pasmami górskimi, powstałym w efekcie wzajemnego oddziaływania czynników meteorologicznych i orograficznych. Polega na występowaniu w atmosferze stacjonarnych fal grawitacyjnych, wzbudzonych w trakcie przepływu powietrza nad przeszkodą terenową o dużej wysokości względnej (ryc. 1, Parczewski, 1953; Schmidt, 1982; Wyszogrodzki, 2001). Można ją porównać, przez analogię mechanizmu powstawania, do ruchu falowego wody w rzece, za progiem skalnym w dnie koryta. 
Fala orograficzna ma istotne znaczenie dla lotnictwa, ze względu na duży zasięg (średnio kilkadziesiąt $\mathrm{km} \mathrm{w}$ poziomie, kilka-kilkanaście $\mathrm{km} \mathrm{w}$ pionie), długi czas występowania (od kilku godzin do kilku dni) oraz wytworzenie się specyficznej lokalnej cyrkulacji atmosferycznej. Wzbudzenie ruchu falowego nad pasmem górskim stwarza dla lotnictwa pozytywne i negatywne następstwa, które oddziałują na bezpieczeństwo i koszt operacji lotniczych. Rozpatrywane zjawisko jest szczególnie ważne dla szybownictwa, ponieważ wstępujące prądy falowe umożliwiają wykonanie lotów rekordowych pod względem długości i wysokości.

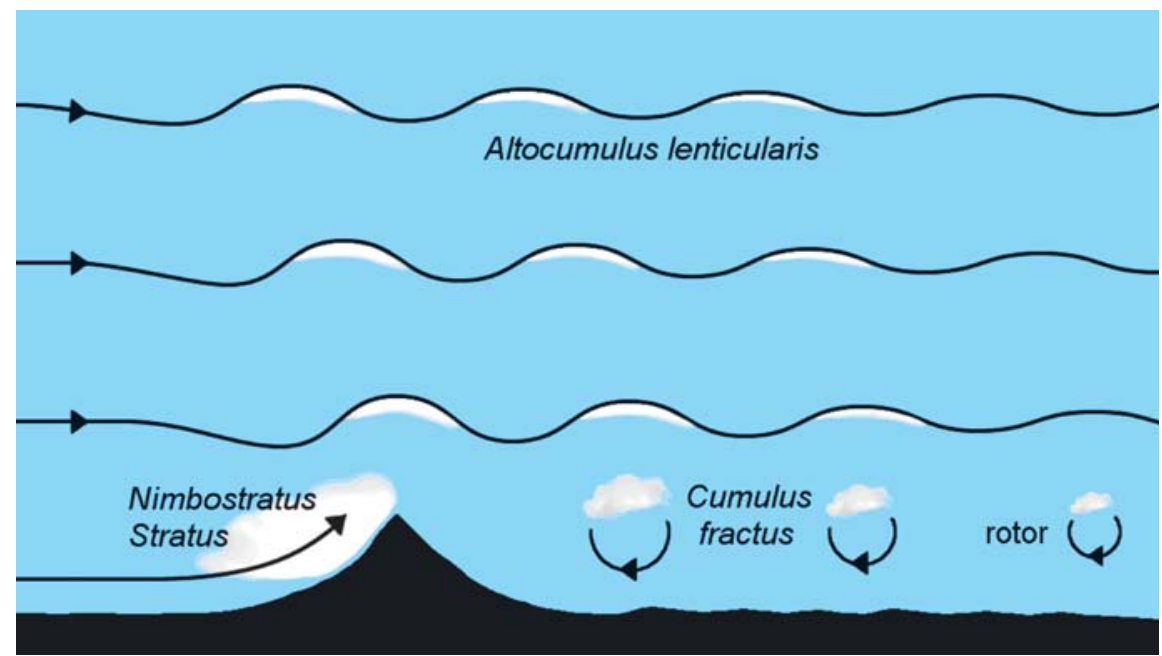

Ryc. 1. Schemat powstawania fali orograficznej

Scheme for mountain lee wave formation

\section{Rozpoznanie fali orograficznej w Karpatach Polskich i jej wykorzystanie w szybownictwie}

W dotychczasowej literaturze fali orograficznej w Karpatach Polskich poświęcono niewiele miejsca, m.in. z powodu późnego odkrycia i poznania mechanizmu powstawania zjawiska ${ }^{1}$. Fala jest także trudna do badania, gdyż do jej tworzenia się dochodzi na dużej wysokości nad ziemią (rzędu setek, a nawet tysięcy metrów), natomiast ruch falowy powietrza jest niedostrzegalny dla oka ludzkiego. Brak badań radiosondażowych w Karpatach Polskich dodatkowo ogranicza rozwój wiedzy o zjawisku.

\footnotetext{
${ }^{1}$ Zjawisko fali orograficznej zostało odkryte w 1933 r. przez niemieckich pilotów - Hansa Deutschmanna i Wolfa Hirtha - w trakcie lotu szybowcowego nad Karkonoszami (Ferguson, 2001).
} 
Badania meteorologiczne fali w Karpatach Polskich zostały zapoczątkowane w Tatrach (Parczewski, 1953, 1959) i do chwili obecnej koncentrują się one na tym obszarze (Schmidt, 2002). Wiedza na jej temat nad pozostałą częścią Karpat Polskich jest zaś fragmentaryczna.

Podstawowym źródłem informacji o fali w Karpatach Polskich są dane lotnicze aeroklubów regionalnych (ryc. 2). Uzyskane w trakcie lotów dane o zjawisku dotyczą głównie jego aspektów istotnych dla szybownictwa. Są one przekazywane ustnie przez pilotów, a nieliczne z nich zostały zebrane i rozpowszechnione w postaci drukowanej (np. Instrukcja ...).

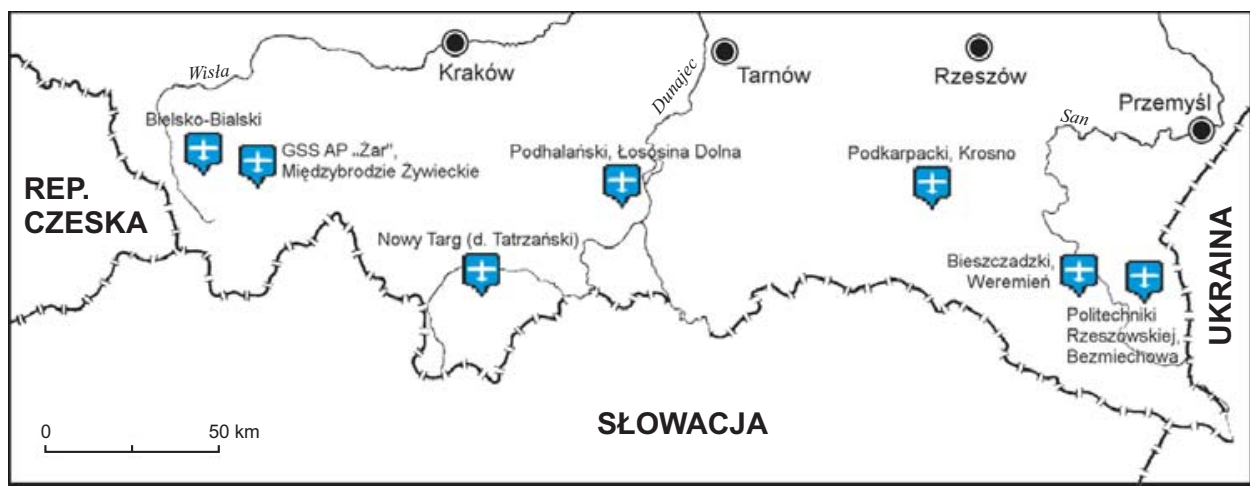

Ryc. 2. Aerokluby regionalne w Karpatach Polskich

Regional aeroclubs in the Polish Carpathians

Pierwszy w Polsce lot szybowcowy z wykorzystaniem fali orograficznej wykonał 20 października 1935 r. w okolicy Bezmiechowej k. Leska R. Drygałła na szybowcu SG-3bis/35, uzyskując wysokość maksymalną w trakcie lotu $2300 \mathrm{~m}$ (Urbanek, 1993).

Intensywny rozwój szybownictwa z wykorzystaniem fali orograficznej w Karpatach Polskich nastąpił od drugiej połowy lat 1950. W 1958 r. w Nowym Targu utworzono wyspecjalizowaną jednostkę szkoleniową Aeroklubu Polskiego - Ośrodek Szybowcowych Lotów Falowych, której zadaniem było organizowanie lotów wysokościowych nad Tatrami z wykorzystaniem fali oraz teoretyczne i praktyczne przygotowywanie pilotów do ich wykonywania. Wieloletnia działalność tego ośrodka (zakończona w 2003 r., wznowiona w 2009 r.) przyczyniła się do powstania prac naukowych na temat fali w Tatrach Polskich (Mozdyniewicz, 1976; Schmidt, 1982, 2002) i podręcznika lotów szybowcowych na tej fali (Świst, 2000); opublikowano także wspomnienia z lotów falowych na tym obszarze (Schiele, 1979). 


\section{Pozycja fali orograficznej w Beskidzie Niskim w podziale regionalnym fali orograficznej Karpat Polskich}

W. Mozdyniewicz (1976) wyróżnił w obrębie fali orograficznej Karpat Polskich 4 jednostki regionalne: falę bielską, falę tatrzańską, falę sądecką oraz falę Beskidu Wschodniego (bieszczadzką). Ostatnia z tych jednostek jest wydzieleniem, które może rodzić pewne wątpliwości. Jej nazwa jest nieprecyzyjna i myląca, ponieważ zgodnie z koncepcją autora obejmuje nie tylko Bieszczady, ale także Beskid Niski. Nazwa ta jest dodatkowo niepoprawna w kontekście regionalizacji fizycznogeograficznej Karpat Polskich (Kondracki, 2002), gdyż drugie z tych pasm należy do Beskidów Środkowych (Karpat Zachodnich), a nie do Beskidów (Karpat) Wschodnich. Zastrzeżenia do słuszności wyróżnienia fali Beskidu Wschodniego (bieszczadzkiej) sensu Mozdyniewicz (1976) wynikają także z faktu, że pasma przyczyniające się do jej wzbudzania - Bieszczady i Beskid Niski - istotnie różnią się rzeźbą terenu (głównie wysokością i orientacją pasm górskich). Na podstawie tego zróżnicowania można domniemywać, że warunki występowania oraz własności fali orograficznej w tej części Karpat Polskich są kształtowane w odmienny sposób (kwestię tę szerzej przedstawiono w dalszej części pracy).

W związku z powyższymi zastrzeżeniami na temat fali Beskidu Wschodniego (bieszczadzkiej) sensu Mozdyniewicz (1976) oraz domniemanym wewnętrznym zróżnicowaniem tej jednostki, uzasadnione wydaje się ograniczenie jej zasięgu tylko do Bieszczadów oraz ich przedpola, a także wyróżnienie nowej jednostki regionalnej fali orograficznej Karpat Polskich - fali Beskidu Niskiego. Drugą z tych jednostek należy utożsamiać z falą wzbudzaną nad Beskidem Niskim i propagującą się na jego północne przedpole.

\section{Cel pracy}

Celem pracy jest scharakteryzowanie fali orograficznej występującej nad polską częścią Beskidu Niskiego i na jego przedpolu. Rozważaniami objęto następujące własności zjawiska:

1) przebieg roczny,

2) uwarunkowania cyrkulacyjne i wiatrowe,

3) częstość,

4) intensywność,

5) zasięg pionowy i poziomy,

6) częstość zachmurzenia falowego i rotorowego oraz towarzyszącego fali zachmurzenia orograficznego,

7) położenie i geometria obszarów występowania wstępujących prądów falowych. 
Celem pracy jest także ustalenie różnic między własnościami fali orograficznej w Beskidzie Niskim i nad pozostałymi pasmami głównymi Karpat Polskich, zwłaszcza w Tatrach. Praktycznym celem pracy jest określenie roli fali orograficznej w Beskidzie Niskim w kształtowaniu meteorologicznych warunków prowadzenia aktywności szybowcowej.

\section{Materiały źródłowe}

Za podstawowy materiałźródłowy uznano Dokumentację szybowcowych akcji lotów falowych Aeroklubu Podkarpackiego. Zawiera ona informacje na temat lotów wykonanych z wykorzystaniem fali orograficznej w Beskidzie Niskim w 26 dniach w latach 1957-1994 (zał. 1). Loty były wykonywane z lotniska w Krośnie (4940'59"N, 214ㄴ'01"E, $280 \mathrm{~m}$ npm.), położonego w odległości około $15 \mathrm{~km}$ od najbardziej na północ wysuniętych pasm Beskidu Niskiego. Główną część dokumentacji stanowią sprawozdania pilotów, zawierające m.in. informacje na temat warunków meteorologicznych w trakcie lotów na lotnisku i wyższych partiach troposfery. Do wielu sprawozdań dołączone są szkice trasy lotu, a także zapisy wysokości położenia szybowca wykonane przy użyciu barografu.

Przedstawiona dokumentacja lotnicza to mały i niekompletny zbiór danych, obejmujący tendencyjnie wybrane przypadki zjawiska. W związku z tym możliwość formułowania na jej podstawie wniosków jest ograniczona. Wykorzystanie dokumentacji podyktowane jest jej jakością (szczegółowy opis sytuacji z falą) oraz gwarancją uwzględnienia w niej przypadków zjawiska o dużej intensywności. Uzasadnieniem wyboru jest także duży zakres czasowy serii danych (38 lat), w tym obejmującym lata, dla których nie ma danych meteorologicznych umożliwiających identyfikację zjawiska w Beskidzie Niskim (np. o chmurach Altocumulus lenticularis, Ac len). Zamierzeniem autora było wykorzystanie dokumentacji lotniczej w możliwie szerokim zakresie, tak by uzyskane dzięki niej wnioski były podstawą do szczegółowych badań meteorologicznych.

Danych dostarczyły także wywiady przeprowadzone z pilotami Aeroklubu Podkarpackiego. Zgromadzone informacje wykorzystano głównie w opisie znaczenia fali w Beskidzie Niskim dla szybownictwa.

Źródłem danych meteorologicznych był Kalendarz typów cyrkulacji w Polsce potudniowej (Niedźwiedź, 2001). Wykorzystano także dane Instytutu Meteorologii i Gospodarki Wodnej o kierunku i prędkości wiatru w latach 1961-1970 w 9 miejscowościach (Baligród, Iwonicz, Krosno, Krynica, Muszyna, Myczkowce, Smolnik, Wysowa).

\section{Fala orograficzna w Beskidzie Niskim}

\section{Przebieg roczny udokumentowanych przypadków zjawiska}

Na podstawie dokumentacji lotniczej można stwierdzić, że fala orograficzna w Beskidzie Niskim występuje głównie w półroczu chłodnym (ryc. 3) - z 26 
dni z tym zjawiskiem na półrocze chłodne przypada 22. Możliwe jest także postawienie hipotezy, że maksimum częstości fali na tym obszarze przypada na jesień, zwłaszcza jej drugą połowę. Najwięcej dni ze zjawiskiem udokumentowanym danymi lotniczymi przypada bowiem na listopad (12) i październik (8). Przedstawione informacje na temat przebiegu rocznego fali w Beskidzie Niskim są zgodne z prawidłowościami odnoszącymi się do Tatr (Mozdyniewicz, 1976; Schmidt, 1982; Świst, 2000). Największa częstość tatrzańskiej fali orograficznej także przypada na półrocze chłodne (maksimum w I i II dekadzie listopada, ibid.). W związku z małą liczebnością analizowanych danych nie jest możliwe stwierdzenie, na którą część roku przypada minimum częstości fali w Beskidzie Niskim. Przez analogię do fali tatrzańskiej (minimum częstości w maju, czerwcu i lipcu - Świst, 2002) można jedynie domniemywać, że nad Beskidem Niskim zjawisko najrzadziej powstaje późną wiosną i latem.

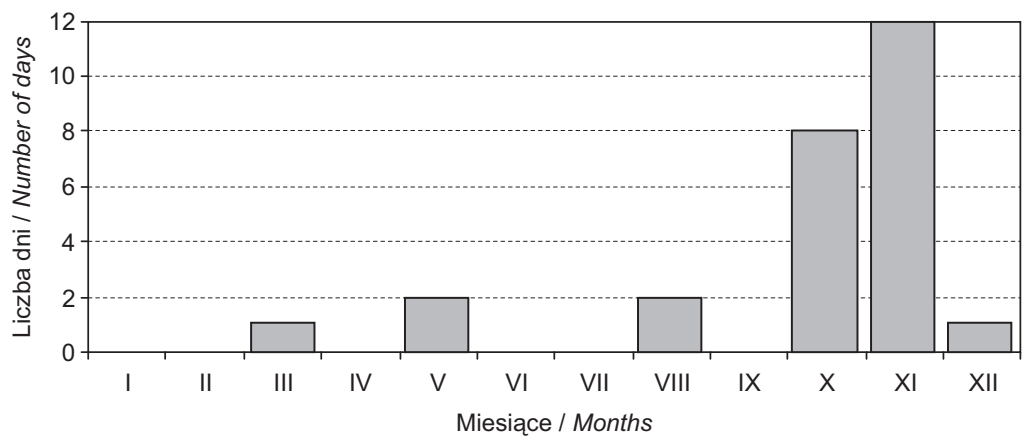

Ryc. 3. Udokumentowane danymi lotniczymi Aeroklubu Podkarpackiego przypadki fali orograficznej w Beskidzie Niskim w poszczególnych miesiącach (dane z lat 1957-1994)

Cases documented by Podkarpacki Aeroclub aerial data of mountain lee waves in the Beskid Niski Mts. in particular months (data from years 1957-1994)

Częste występowanie fali w Beskidzie Niskim w półroczu chłodnym jest prawdopodobnie uwarunkowane stanem równowagi atmosfery. W półroczu tym w atmosferze często występuje równowaga stała, zwłaszcza przypadki inwersji temperatury powietrza, które sprzyjają wzbudzaniu fal w atmosferze. Dominująca natomiast w półroczu ciepłym równowaga chwiejna oraz obojętna uniemożliwia lub w dużym stopniu utrudnia ich powstawanie (Mozdyniewicz, 1976). 


\section{Uwarunkowania cyrkulacyjne i wiatrowe}

Fala orograficzna w Beskidzie Niskim występuje najczęściej przy adwekcji powietrza z południa (16 z 26 przypadków, ryc. 4), dość często zjawisko występuje także w sytuacji napływu powietrza z południowego zachodu (7 przypadków). Zaledwie w jednym przypadku w trakcie wytworzenia się fali występowała adwekcja powietrza z południowego wschodu.

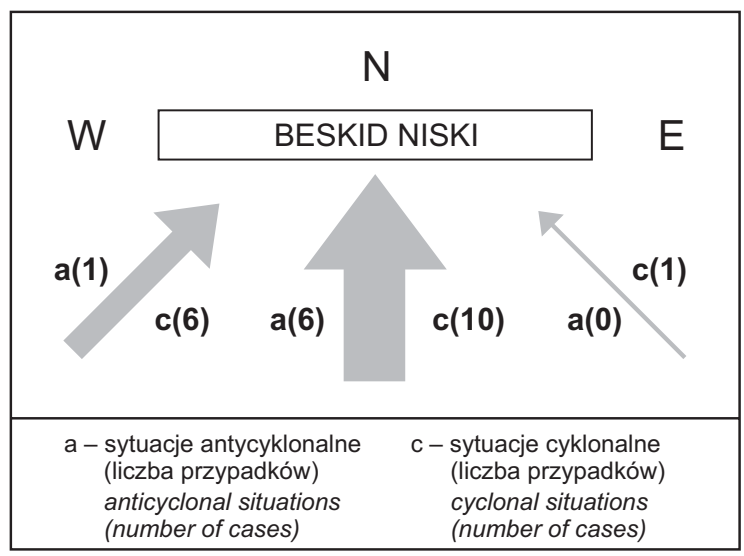

Ryc. 4. Warunki cyrkulacyjne w trakcie występowania fali orograficznej w Beskidzie Niskim. Sytuacje adwekcyjne, na podstawie: Niedźwiedź (2001) oraz Dokumentacja...

(dane z lat 1957-1994). Strzałkami oznaczono kierunek adwekcji.

Szerokość strzałek proporcjonalna do częstości zjawiska.

Atmospheric circulations coinciding with the occurrence of mountain lee waves in the Beskid

Niski Mts. Advectional situations, based on: Niedźwiedź (2001) and Podkarpacki Aeroclub documentation of mountain lee wave gliding campaigns (data from years 1957-1994).

Arrows show direction of air advection, while their widths are proportional to the phenomenon frequency.

Wśród 26 dni z falą orograficzną znalazły się dwa (23.08.1986, 29.10.1989), w których warunki cyrkulacyjne miały charakter sytuacji nieadwekcyjnych (bruzda niskiego ciśnienia). Na podstawie wiedzy ogólnej na temat fali orograficznej można stwierdzić, że ich obecność nie sprzyja rozwojowi zjawiska, ponieważ warunkiem koniecznym jest przepływ powietrza nad przeszkodą terenową z dużą prędkością. Wyjaśnieniem tej pozornej sprzeczności może być występowanie w tych dniach lokalnego zróżnicowania warunków cyrkulacyjnych w Polsce południowej, zwłaszcza, że Beskid Niski położony jest w jej skrajnej części. Dowodem na prawdziwość tej koncepcji są dane meteorologiczne pochodzące ze sprawozdań pilotów. Zgodnie z ich informacjami na lotnisku w Krośnie w pierw- 
szym z wymienionych dni występował wiatr południowy o prędkości $12-15 \mathrm{~m} \cdot \mathrm{s}^{-1}$, natomiast w drugim - wiatr z kierunku SSW i S o prędkości 8-12 $\mathrm{m} \cdot \mathrm{s}^{-1}$.

We wszystkich przypadkach, w których na lotnisku w Krośnie prowadzono obserwacje meteorologiczne, fala występowała przy wietrze z udziałem składowej południowej. Najczęściej notowany nie był jednak kierunek południowy (drugi w kolejności), tylko SSE. Kierunki SW i SE były obserwowane bardzo rzadko. Charakterystyczna dla większości analizowanych przypadków była mała różnica między kierunkiem wiatru dolnego (na lotnisku) i górnego (na wysokości rozpoczęcia lotu swobodnego szybowca, około $500 \mathrm{~m}$ nad lotniskiem).

$\mathrm{Na}$ podstawie danych meteorologicznych z dokumentacji lotniczej można stwierdzić, że najmniejsza prędkość wiatru niezbędna do wzbudzenia fali orograficznej w Beskidzie Niskim wynosi około $7 \mathrm{~m} \cdot \mathrm{s}^{-1}$ na wysokości szczytowych partii pasma (600-1000 m npm.). Próg ten jest zgodny z wnioskami W. Parczewskiego (1953), według którego minimalna prędkość wiatru konieczna do wywołania fali nad przeszkodą terenową o wysokości względnej $300 \mathrm{~m}$ wynosi $6 \mathrm{~m} \cdot \mathrm{s}^{-1}$.

Fala w Beskidzie Niskim częściej występuje w sytuacjach cyklonalnych niż antycyklonalnych (odpowiednio 17 i 7 przypadków). Własności tego zjawiska w Karpatach Polskich różnicują się w zależności od warunków cyrkulacyjnych. Falę wytworzoną w obrębie ośrodka niżowego charakteryzuje - w porównaniu do fali w zasięgu ośródka wyżowego - krótszy czas występowania, słabszy rozwój pionowy i większe zachmurzenie (Mozdyniewicz, 1976; Schmidt, 2002).

Przeanalizowano także zależność między występowaniem fali w Beskidzie Niskim a stabilnością cyrkulacji atmosferycznej. W związku z przedstawionymi wątpliwościami z rozważań wyłączono dwie sytuacje nieadwekcyjne. Najczęściej fala występowała w trakcie krótkiego, zwykle 1- lub 2-dniowego, okresu panowania jednakowych warunków cyrkulacyjnych (ryc. 5). Zjawisko notowano także w trakcie takich okresów o większej długości (maksymalnie 9-dniowych). Na tej podstawie można stwierdzić, że do powstania fali w Beskidzie Niskim nie jest konieczne występowanie stabilnych warunków cyrkulacyjnych. W przypadku spełnienia wszystkich niezbędnych warunków wzbudzenia fali, może ona występować w krótkotrwałych sytuacjach cyrkulacyjnych.

\section{Częstość}

Można przypuszczać, że fala orograficzna występuje w Beskidzie Niskim częściej niż nad pozostałymi pasmami głównymi Karpat Polskich, a to dzięki małej wysokości kompleksu, zróżnicowanej orientacji jego pasm, a także występowaniu w sąsiedztwie wyższych pasm górskich (Beskid Sądecki, Bieszczady).

Minimalna prędkość wiatru wymagana do wzbudzenia fali orograficznej jest różna w zależności od wysokości względnej przeszkody terenowej. Im 
A

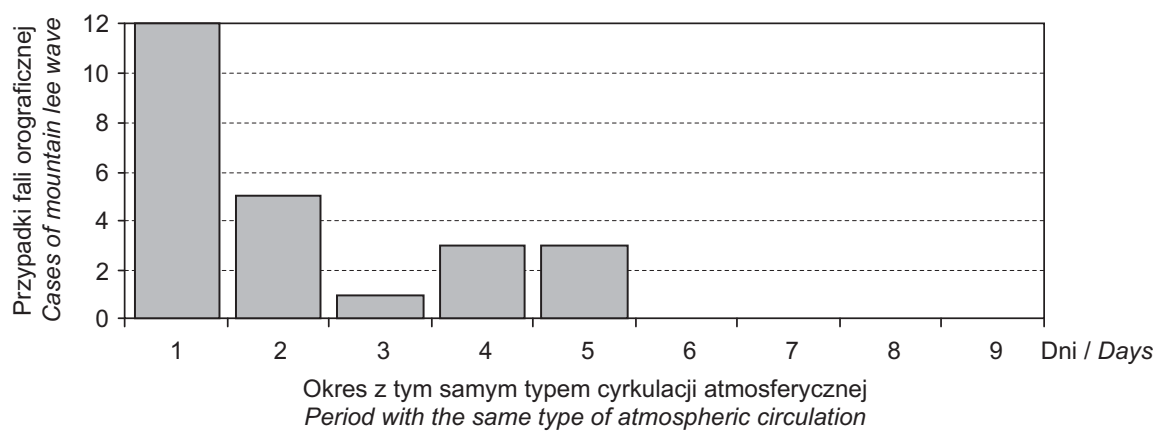

B

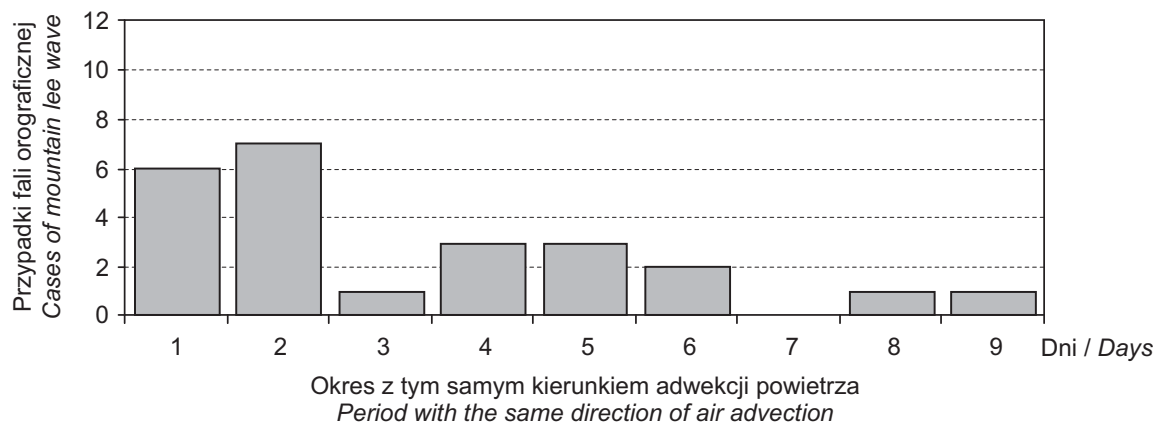

Ryc. 5. Zależność między występowaniem fali orograficznej w Beskidzie Niskim a stabilnością cyrkulacji atmosferycznej: A - zależność od typu cyrkulacji atmosferycznej (klasyfikacja obejmuje 21 typów); B - zależność od kierunku adwekcji powietrza Opracowanie własne na podstawie: T. Niedźwiedź (2001) oraz Dokumentacja... (dane z lat 1957-1994).

Relationship between occurrence of mountain lee waves in the Beskid Niski Mts. and stability of atmospheric circulation: A - relationship between occurrence of the phenomenon and type of atmospheric circulation (classification includes 21 types); $\mathrm{B}$ - relationship between occurrence of the phenomenon and direction of air advection

Own elaboration based on: T. Niedźwiedź (2001) and Podkarpacki Aeroclub documentation of mountain lee wave gliding campaigns (data from years 1957-1994).

wyższa przeszkoda, tym większa prędkość wiatru niezbędna do powstania fali (Parczewski, 1953). W związku z tym w Beskidzie Niskim minimalna prędkość wiatru wymagana do wzbudzenia zjawiska (około $7 \mathrm{~m} \cdot \mathrm{s}^{-1}$ ) jest mniejsza niż nad pozostałymi pasmami głównymi Karpat Polskich (np. w Tatrach 9,5 $\mathrm{m} \cdot \mathrm{s}^{-1}$ - Schmidt, 2002). Można zatem stwierdzić, że Beskid Niski jest pasmem, nad którym fala może być najwcześniej inicjowana.

Orientacja pasm w Beskidzie Niskim jest zróżnicowana - na zachodzie osie grzbietów mają przebieg równoleżnikowy, na wschodzie - NW-SE. W tej sytuacji zakres kierunku wiatru sprzyjającego wzbudzaniu fali orograficznej jest tu większy niż w przypadku pasm o jednakowej orientacji. Zakładając 
położenie skrajnych kierunków pod kątem $45^{\circ}$ do rozciągłości pasma, zakres ten w Beskidzie Niskim wynosi W-SE.

Do dużej częstości fali w Beskidzie Niskim przyczynia się także konfiguracja pasm górskich we wschodniej części Karpat Polskich. Przy adwekcji powietrza z południa, Beskid Niski (wyraźnie niższy niż Sądecki i Bieszczady), jest miejscem dogodnego przepływu powietrza ku północy. W sytuacji tej, na skutek efektu tunelowego, dochodzi do lokalnego wzrostu prędkości ruchu powietrza (tab. 1). Fala w Beskidzie Niskim może dzięki temu powstać nawet wtedy, gdy nad pozostałymi pasmami głównymi Karpat Polskich prędkość wiatru jest zbyt mała do jej utworzenia się.

Tabela 1. Charakterystyki wiatru z kierunków SW, SSW, S, SSE, SE w Beskidzie Sądeckim, Beskidzie Niskim i w Bieszczadach, 1961-1970

Characteristics of SW, SSW, S, SSE and SE winds in the Beskid Sądecki, Beskid Niski and Bieszczady Mts., 1961-1970

\begin{tabular}{|c|c|c|c|c|c|c|c|c|}
\hline \multirow{2}{*}{$\begin{array}{l}\text { Wiatr / Wind } \\
\text { SW, SSW, S, } \\
\text { SSE, SE }\end{array}$} & \multicolumn{2}{|c|}{ Beskid Sądecki } & \multicolumn{4}{|c|}{ Beskid Niski } & \multicolumn{2}{|c|}{ Bieszczady } \\
\hline & Muszyna & Krynica* & Wysowa & Krosno & Iwonicz & $\begin{array}{c}\text { Smol- } \\
\text { nik* }^{*}\end{array}$ & Baligród & $\begin{array}{l}\text { Mycz- } \\
\text { kowce* }\end{array}$ \\
\hline $\begin{array}{l}\text { Średnia prędkość } \\
\text { Mean speed } \\
\left(\mathrm{m} \cdot \mathrm{s}^{-1}\right)\end{array}$ & 3,0 & 3,0 & 4,3 & 5,7 & 3,7 & 3,8 & 2,5 & 3,6 \\
\hline $\begin{array}{l}\text { Częstość (\%) wia- } \\
\text { tru o prędkości: } \\
\text { Frequency (\%) of } \\
\text { wind speed: }\end{array}$ & & & & & & & & \\
\hline $\begin{array}{l}\geq 5 \mathrm{~m} \cdot \mathrm{s}^{-1} \\
\geq 7 \mathrm{~m} \cdot \mathrm{s}^{-1} \\
\geq 10 \mathrm{~m} \cdot \mathrm{s}^{-1}\end{array}$ & $\begin{array}{r}20,0 \\
7,7 \\
0,7 \\
\end{array}$ & $\begin{array}{r}20,0 \\
7,0 \\
0,6 \\
\end{array}$ & $\begin{array}{r}43,7 \\
21,5 \\
3,5 \\
\end{array}$ & $\begin{array}{r}53,0 \\
33,5 \\
14,7 \\
\end{array}$ & $\begin{array}{r}26,1 \\
14,6 \\
8,6 \\
\end{array}$ & $\begin{array}{r}17,2 \\
16,8 \\
1,6 \\
\end{array}$ & $\begin{array}{r}12,1 \\
5,9 \\
1,9 \\
\end{array}$ & $\begin{array}{r}28,0 \\
12,0 \\
2,9 \\
\end{array}$ \\
\hline
\end{tabular}

* kompletność danych / data completeness: Krynica - 97,5\%, Smolnik - 81,7\%, Myczkowce - 85,3\%.

Źródło danych: Instytut Meteorologii i Gospodarki Wodnej, Warszawa.

Data source: Institute of Meteorology and Water Management, Warsaw.

\section{Intensywność ruchu falowego}

Warunki orograficzne Beskidu Niskiego oddziałują nie tylko na częstość, lecz także na intensywność ruchu falowego. Mała wysokość pasma powoduje, że generowaną tam falę charakteryzuje mała intensywność oraz niewielka prędkość prądów falowych. Według dokumentacji lotniczej prędkość ta wynosi maksymalnie $6 \mathrm{~m} \cdot \mathrm{s}^{-1}$ (w Tatrach 13-15 $\mathrm{m} \cdot \mathrm{s}^{-1}-$ Schmidt, 1982). 
Cechą fali w Beskidzie Niskim jest także słaby, jak na Karpaty Polskie, rozwój cyrkulacji rotorowej ${ }^{2}$. Według dokumentacji lotniczej prędkość prądów rotorowych wynosi maksymalnie $5 \mathrm{~m} \cdot \mathrm{s}^{-1}$ (w Tatrach $19-21 \mathrm{~m} \cdot \mathrm{s}^{-1}-$ Schmidt, 1982). Zjawisko to ma charakter wtórny w stosunku do fali, dlatego jego mała intensywność jest konsekwencją małej prędkości prądów falowych.

Falę w Beskidzie Niskim prawdopodobnie cechują częste zmiany intensywności, co jest pochodną zmiennych warunków wiatrowych. Przepływ powietrza nad tym pasmem często ma charakter porywisty, zwłaszcza w okolicy Przełęczy Dukielskiej (wiatry rymanowskie - Lewińska, 1958). Zmiany prędkości wiatru powodują zmianę długości i amplitudy fal w atmosferze. Skutkiem tego jest zróżnicowanie, w krótkich odstępach czasu, położenia i prędkości prądów falowych oraz rotorowych.

\section{Zasięg pionowy}

Według W. Mozdyniewicza (1976) podstawa najniższych fal orograficznych znajduje się w przybliżeniu na wysokości szczytowych partii przeszkody terenowej. Opierając się na tym stwierdzeniu można uznać, że falowy ruch powietrza nad Beskidem Niskim pojawia się powyżej $700 \mathrm{~m}$ npm. (minimalnie 500, maksymalnie 1000). Informację tę potwierdzają dane empiryczne pilotów, zgodnie z którymi wstępujące prądy falowe występują w okolicy Krosna od wysokości 400-700 m nad poziomem lotniska (700-1000 m npm.).

Według W. Parczewskiego (1953) maksymalna wysokość, na której możliwe jest występowanie fali orograficznej, jest równa 21-krotności wysokości względnej przeszkody terenowej przyczyniającej się do jej wzbudzania. Na tej podstawie można stwierdzić, że fala nad Beskidem Niskim może rozwijać się do wysokości 4500-8700 m npm., przy założeniu poziomu odniesienia 300 m npm. oraz wysokości względnej pasma 200-400 m. Szacunki te są potwierdzone danymi z dokumentacji lotniczej. Górna granica występowania fali została dotychczas stwierdzona na $4600 \mathrm{~m}$ nad poziomem lotniska ${ }^{3}$, jednak prawdopodobnie mogłaby ona znajdować się jeszcze wyżej. Mogą o tym świadczyć obserwacje chmur soczewkowatych w trakcie lotów falowych (np. 26 października $1984 \mathrm{r}$. J. Gruszecki dostrzegł te chmury o podstawie na wysokości około $5000 \mathrm{~m}$ nad poziomem lotniska).

Na podstawie przedstawionych informacji można stwierdzić, że maksymalny pionowy zasięg fali w Beskidzie Niskim wynosi od około 4000 m nad najniższymi partiami pasma do około $8000 \mathrm{~m}$ nad partiami najwyższymi. Zasięg pionowy zjawiska rozszerza się wraz ze wzrostem prędkości wiatru (tab. 2). Najkorzystniejsze warunki rozwoju fali występują w przypadku wiatru o kierunku SSE,

\footnotetext{
${ }^{2}$ Rotor to wir powietrza o osi poziomej występujący w warstwie podfalowej, zwykle pod grzbietem fali. Średnica rotoru wynosi od kilkuset metrów do kilku kilometrów.

${ }^{3}$ Dokonał tego 8 listopada 1969 r. pilot Z. Chodorowski w trakcie lotu na szybowcu Bocian.
} 
S i SSW. Jeśli kierunek wiatru nie jest zawarty w przedziale wartości optymalnych, zasięg pionowy zjawiska jest ograniczony.

Tabela 2. Zasięg pionowy fali orograficznej w Beskidzie Niskim

Vertical range of a mountain lee wave in the Beskid Niski Mts.

\begin{tabular}{|c|c|c|}
\hline \multirow{2}{*}{$\begin{array}{c}\text { Prędkość wiatru } \\
\text { Wind speed } \\
\left(\mathrm{m} \cdot \mathrm{s}^{-1}\right)\end{array}$} & \multicolumn{2}{|c|}{$\begin{array}{l}\text { Położenie granicy występowania falowego ruchu powietrza (m npm.) } \\
\text { Altitude of mountain lee wave boundary ( } m \text { a.s.l.) }\end{array}$} \\
\hline & dolnej / lower & górnej / upper \\
\hline $7 \div 10$ & minimalnie /minimal: & $2000 \div 3000$ \\
\hline $10 \div 15$ & średnio /mean: & $3000 \div 4000$ \\
\hline$>15$ & maksymalnie /maximal: 1000 & $4000 \div 4500(8700)^{*}$ \\
\hline
\end{tabular}

* przy założeniu wysokości względnej Beskidu Niskiego 200 (400) m.

on the assumption that the relative height of the Beskid Niski Mts. is 200 (400) m.

Źródło danych: Dokumentacja... (dane z lat 1957-1994) oraz zależność według Parczewskiego (1953) i Mozdyniewicza (1976).

Data source: Podkarpacki Aeroclub documentation of mountain lee wave gliding campaigns (from years 1957-1994) and conclusions arrived at by Parczewski (1953) and Mozdyniewicz (1976).

Maksymalny zasięg pionowy fali w Beskidzie Niskim w porównaniu do pozostałych pasm głównych Karpat Polskich jest stosunkowo mały. W Tatrach jest $2 \div 3$-krotnie większy, choć podstawa najniższych fal znajduje się tam około 1000 m wyżej niż nad Beskidem Niskim. Dotychczas najwyżej położone prądy falowe pochodzenia orograficznego nad Tatrami udokumentowano na wysokości $12560 \mathrm{~m} \mathrm{npm.}{ }^{4}$

\section{Zasięg poziomy}

W związku z brakiem odpowiednich danych, lotniczych i meteorologicznych, trudno stwierdzić, jaki jest zasięg poziomy fali orograficznej w Beskidzie Niskim. Można go jednak oszacować na podstawie dostępnych informacji na temat tatrzańskiej fali orograficznej. Na podstawie maksymalnego zasięgu poziomego tej fali (około $100 \mathrm{~km}$ - Ostrowski, 1999), a także $2 \div 3$-krotnie większej wysokości Tatr niż Beskidu Niskiego, można przypuszczać, że zasięg fali w Beskidzie Niskim może wynosić nie więcej niż 50 km. Przyjmując za miejsce odniesienia pasma położone w połowie szerokości Beskidu Niskiego oznacza to, że wzbudzona nad nimi fala o zasięgu poziomym $20 \mathrm{~km}$ będzie sięgała do linii

\footnotetext{
${ }^{4}$ Dokonali tego 5 listopada 1966 r. S. Józefczak (pilot) i J. Tarczoń (pasażer) na szybowcu Bocian. W trakcie tego lotu ustanowiono aktualne do dziś szybowcowe rekordy Polski - wysokości absolutnej oraz przewyższenia (11 $680 \mathrm{~m})$.
} 
Jasło-Krosno-Sanok, natomiast o zasięgu 40 km - linii Pilzno-Strzyżów-Dynów. Szacunki te potwierdzają dane empiryczne pilotów (patrz rozdział Charakterystyka obszarów... - pole falowe IV).

\section{Zachmurzenie}

W trakcie fali orograficznej w Beskidzie Niskim, w porównaniu do pozostałych pasm głównych Karpat Polskich, obserwuje się mniejszą częstość silnie rozwiniętego zachmurzenia falowego (głównie Ac len, fot. 1) i rotorowego (Cumulus fractus, Cu fra), a także większą częstość fali „bezchmurnej”. Przyczyną tego jest mała intensywność ruchu falowego i cyrkulacji rotorowej na przedpolu Beskidu Niskiego.

Mała intensywność fali w Beskidzie Niskim ma także odzwierciedlenie w wyglądzie chmur falowych. W przypadku słabego lub umiarkowanego ruchu falowego chmury te mają jedynie lekko zarysowany kształt soczewkowaty, zwykle są one rozmyte, rzadko tworzą wielopiętrowy system zachmurzenia. Jeśli natomiast fala cechuje się dużą intensywnością, następuje rozwój typowych chmur soczewkowatych. Wówczas nad Beskidem Niskim może

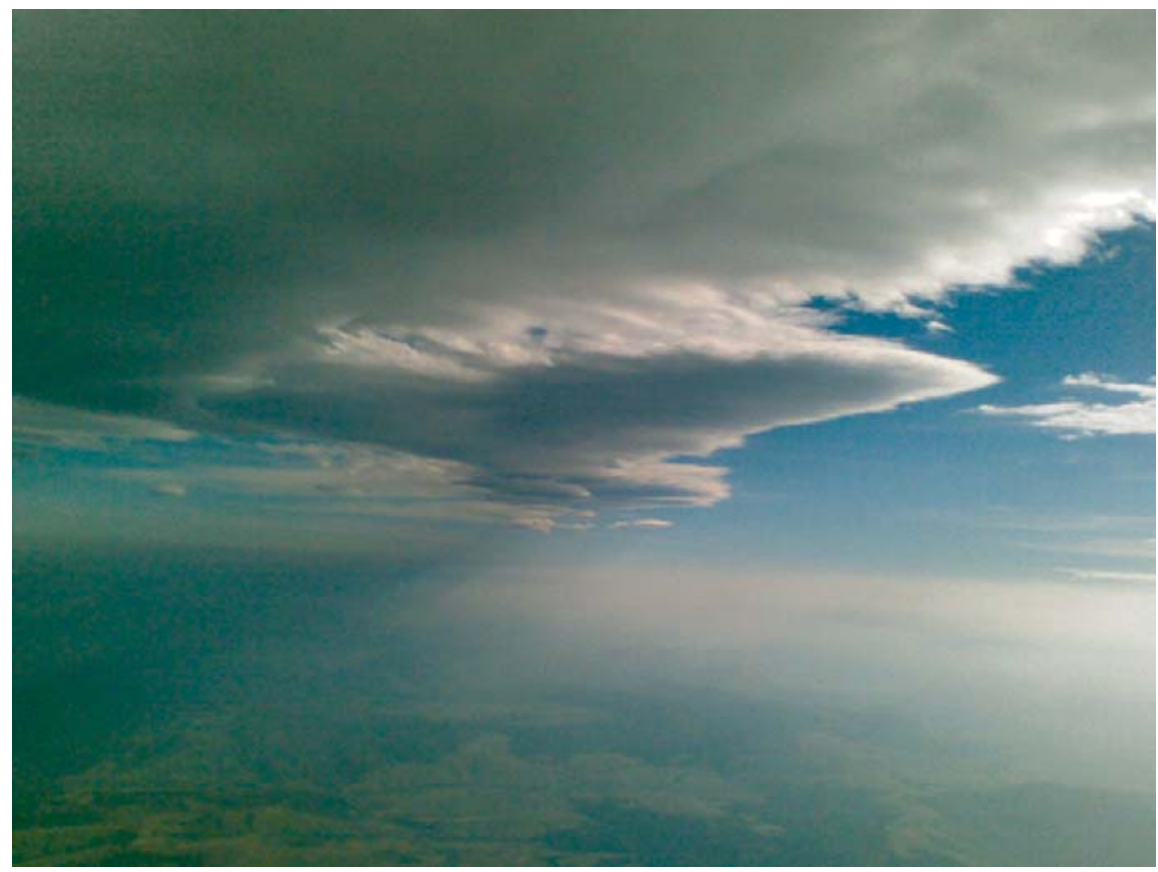

Fot. 1. Pasmo chmur Altocumulus lenticularis w trakcie występowania fali orograficznej w Beskidzie Niskim w dniu 29 października 2008 r. (fot. Aeroklub Podkarpacki)

Belt of Altocumulus lenticularis cloud at the time of occurrence of a mountain lee wave in the Beskid Niski Mts., 29th October 2008 (photo from the Podkarpacki Aeroklub) 
także dochodzić do powstawania pojedynczej chmury Ac len o rozciągłości kilkudziesięciu km. Powyższe wnioski są potwierdzone obserwacjami pilotów (m.in. Z. Szubry i M. Markiewicza dokonanych w trakcie lotów odpowiednio 7.11.1957 i 23.08.1986).

Oddziaływanie Beskidu Niskiego na zachmurzenie współwystępujące z falą obejmuje także chmury piętra dolnego, które powstają w trakcie przepływu powietrza nad przeszkodą terenową. W tym przypadku czynnikiem decydującym o częstości i wielkości zachmurzenia jest położenie poziomu kondensacji pary wodnej. Mała wysokość Beskidu Niskiego powoduje, że deformacja pola przepływu powietrza jest mniejsza niż nad pozostałymi pasmami głównymi Karpat Polskich, mniejsze jest więc prawdopodobieństwo osiągnięcia wysoko położonego poziomu kondensacji pary wodnej oraz powstania chmur orograficznych (ryc. 6A).

Inne są warunki rozwoju chmur, gdy poziom kondensacji pary wodnej zalega na małej wysokości (ryc. 6B). W tym przypadku powstawanie chmur jest możliwe na dowietrznych stokach Beskidu Niskiego i pozostałych pasm Karpat Polskich. Jednocześnie Beskid Niski, ze względu na małą wysokość, w mniejszym stopniu niż pozostałe pasma ogranicza przemieszczanie się

Beskid Niski
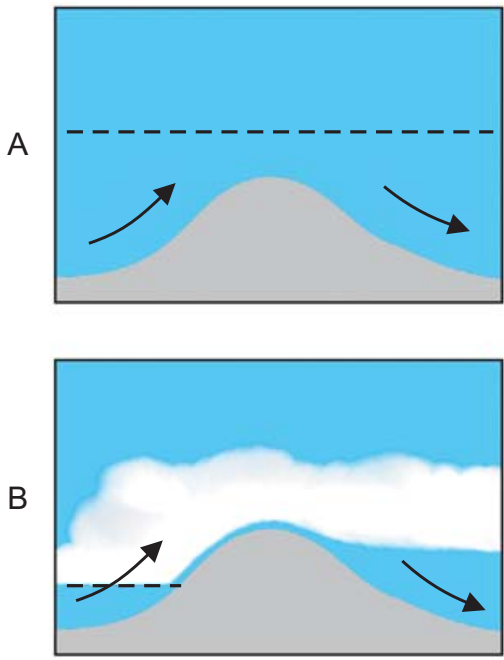

Tatry I Tatra Mts.
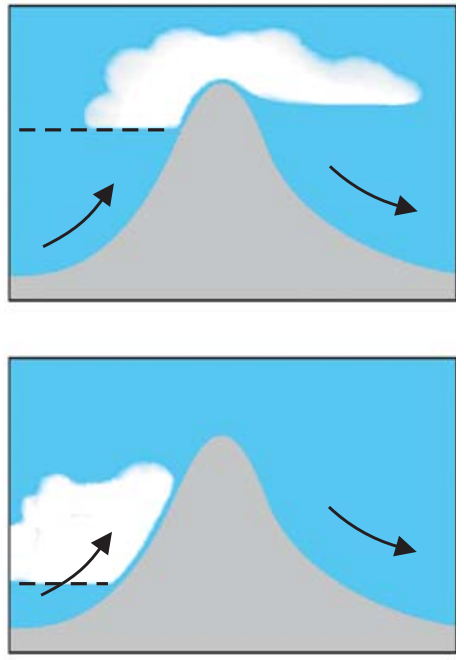

poziom kondensacji pary wodnej water vapour condensation level

Ryc. 6. Zależność między położeniem poziomu kondensacji pary wodnej a zachmurzeniem orograficznym w Beskidzie Niskim i w Tatrach współwystępującym z falą orograficzną

Relationship between position of water vapour condensation level and orographic cloud cover in the Beskid Niski and Tatra Mts. accompanying a mountain lee wave 
chmur w kierunku zgodnym z kierunkiem adwekcji powietrza. Tym samym chmury piętra dolnego po zawietrznej stronie Beskidu Niskiego występują częściej niż nad pozostałymi pasmami.

\section{Znaczenie fali orograficznej w Beskidzie Niskim dla szybownictwa}

Ośrodkiem lotniczym, w działalności którego jest wykorzystywana fala orograficzna w Beskidzie Niskim, jest Aeroklub Podkarpacki w Krośnie. Loty falowe organizowane przez ten aeroklub są wykonywane nad wschodnią częścią Beskidu Niskiego oraz jego przedpolem, najczęściej w wycinku atmosfery, którego zachodnią granicę stanowi odcinek Jasło-Nowy Żmigród-Krempna, wschodnią - Brzozów-Bukowsko-Komańcza, natomiast południową - granica państwa.

Brak w literaturze szczegółowego opisu fali w Beskidzie Niskim ogranicza możliwość jej prognozowania, a tym samym podejmowania decyzji o terminie i miejscu wykonywania lotów falowych. Kwestia ta nabiera obecnie szczególnego znaczenia z uwagi na informację, że wkrótce w Krośnie ma powstać ponadregionalne centrum szkolenia lotniczego. Jego zadaniem ma być teoretyczne i praktyczne kształcenie pilotów prowadzone w ramach rozwoju działalności stowarzyszenia Dolina Lotnicza ${ }^{5}$. Poniższe rozważania mogą pomóc lepiej poznać zjawisko oraz przyczynić się do uwzględnienia lotów falowych w programie szkolenia.

\section{Charakterystyka obszarów występowania prądów falowych}

Obszary występowania prądów wstępujących i zstępujących związanych z falą orograficzną Beskidu Niskiego są powtarzalne. Są to naprzemianległe pasy o mniej więcej stałej szerokości, zorientowane równolegle do pasma górskiego. Pierwszy pas - położony w bezpośrednim sąsiedztwie pasma górskiego - charakteryzuje obecność prądów wstępujących. W tym pasie, a także w przylegającym do niego pasie prądów zstępujących, intensywność pionowego ruchu powietrza jest największa. W kolejnych pasach prędkość wznoszenia i opadania powietrza jest coraz mniejsza, z powodu tłumienia ruchu falowego wraz ze wzrostem odległości od pasma górskiego.

Nad polską częścią Beskidu Niskiego oraz jego przedpolem można wyróżnić po 3 pasy prądów wstępujących oraz zstępujących. Możliwe, że w przypadku intensywnego rozwoju fali występują również kolejne pasy położone dalej na północ, jednak przypuszczenie to nie zostało na razie potwierdzone. Pasy prądów wstępujących są wykorzystywane w trakcie lotów szybowcowych i nazywane przez pilotów polami falowymi. Charakterystyczną cechą pól jest

\footnotetext{
${ }^{5}$ Stowarzyszenie Dolina Lotnicza - organizacja założona w 2003 r., skupiająca obecnie 80 przedsiębiorstw oraz instytucji związanych z lotnictwem, które znajdują się w Polsce południowowschodniej, zwłaszcza w województwie podkarpackim.
} 
ich zakrzywienie ku południowi w części wschodniej, uwarunkowane zmianą orientacji pasm Beskidu Niskiego z równoleżnikowej na NW-SE (ryc. 7).

Pole falowe I jest usytuowane w odległości około $5 \mathrm{~km}$ na północ od granicy państwa, w sąsiedztwie miejscowości: Krempna-Tylawa (pole Ia), Daliowa-Wola Niżna (pole Ib) oraz Wisłok Wielki-Komańcza (pole Ic).

Mimo że pole I charakteryzuje obecność najsilniejszych prądów wstępujących, w dotychczasowej działalności Aeroklubu Podkarpackiego było ono wykorzystywane sporadycznie. Przyczyną jest ograniczona możliwość wprowadzania szybowców w obręb tego pola - lot zespołu samolot-szybowiec do pola I (około $25 \mathrm{~km}$ od lotniska) jest kosztowny, natomiast dotarcie tam w locie swobodnym z pola II jest trudne ze względu na występowanie między nimi pasa prądów zstępujących. Kilkakrotnie piloci podejmowali próby przelotu tego odcinka (m.in. Z. Kwiatek - 28.10.1959 oraz W. Ostrowski - 23.08.1986), jednak kończyły się one niepowodzeniem. Dotarcie do pola I uniemożliwiła intensywna utrata wysokości w trakcie lotu pod wiatr o prędkości około $15 \mathrm{~m} \cdot \mathrm{s}^{-1}$ oraz występowanie prądów zstępujących (około $5 \mathrm{~m} \cdot \mathrm{s}^{-1}$ ).

Pole falowe II znajduje się w odległości około $10 \mathrm{~km}$ na północ od pola I. Ma postać regularnego pasa o szerokości około $5 \mathrm{~km}$, położonego na linii Nowy Żmigród-Równe-Iwonicz-Rymanów-Zbiornik Sieniawski-Bukowsko. Do jego powstawania przyczynia się w części zachodniej Pasmo Magurskie, w części środkowej Beskid Dukielski, natomiast w części wschodniej Pasmo Bukowicy. Na kształtowanie tego pola wpływa także Pogórze Jasielskie oraz Wzgórza Rymanowskie.

Pole II jest najczęściej wykorzystywanym przez Aeroklub Podkarpacki polem falowym. Znajduje się stosunkowo blisko lotniska (około $10 \mathrm{~km}$ ), ponadto występują w nim prądy wstępujące o prędkości porównywalnej z polem I. Tę drugą cechę pola warunkuje stosunkowo duża wysokość pasm górskich, zwłaszcza w północnej części Beskidu Dukielskiego.

Średnia prędkość prądów wstępujących w polu II wynosi $2 \div 3 \mathrm{~m} \cdot \mathrm{s}^{-1}$, natomiast maksymalna $-6 \mathrm{~m} \cdot \mathrm{s}^{-1}$. W warstwie podfalowej może dochodzić do powstawania rotorów. Mimo stosunkowo dużej prędkości cyrkulacji powietrza w tych strukturach (średnio około $3 \mathrm{~m} \cdot \mathrm{s}^{-1}$, maksymalnie $5 \mathrm{~m} \cdot \mathrm{s}^{-1}$ ) są one rzadko wykorzystywane w trakcie lotów, ze względu na dużą mobilność oraz obecność silnej turbulencji.

Maksymalna wysokość lotu w tym polu wynosi zwykle 3000-4000 m nad poziomem lotniska w Krośnie. W sprzyjających warunkach meteorologicznych możliwe jest uzyskanie przewyższenia $\geq 3000 \mathrm{~m}^{6}$.

Manewrem praktykowanym w trakcie lotów w polu II jest lot wahadłowy równolegle do rozciągłości pola, najczęściej w obrębie jego wschodniej części. Dzięki temu możliwe jest dotarcie na przedpole tych partii Beskidu Niskiego,

\footnotetext{
${ }^{6}$ Uzyskanie w trakcie lotu przewyższenia $\geq 3000 \mathrm{~m}$ jest jednym z trzech kryteriów uzyskania Złotej Odznaki Szybowcowej ( $\geq 5000$ m - Diamentowej Odznaki Szybowcowej).
} 


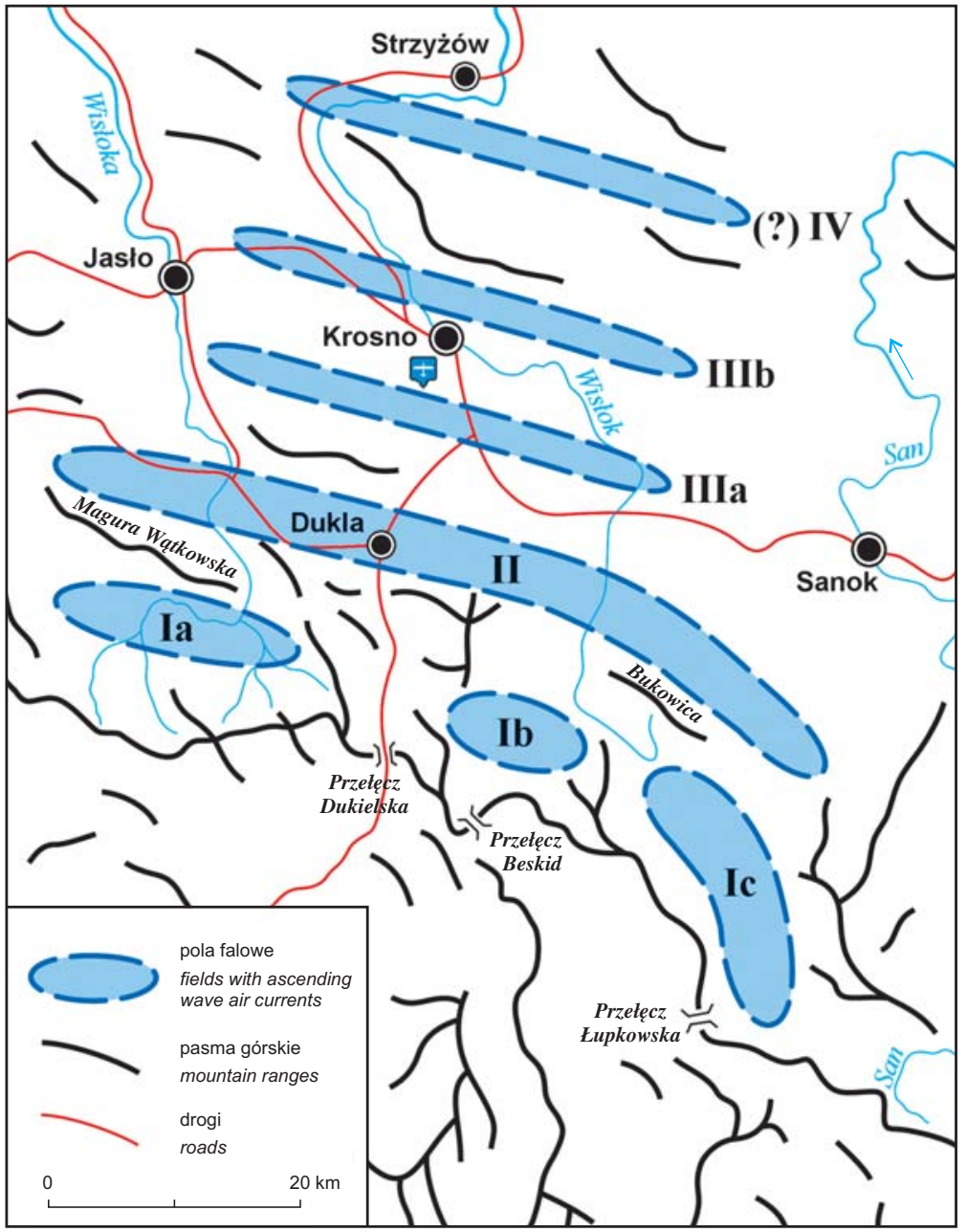

Ryc. 7. Pola falowe we wschodniej części Beskidu Niskiego i na jego przedpolu w trakcie występowania fali orograficznej (objaśnienia w tekście)

Fields with ascending wave air currents in the eastern part of the Beskid Niski and their foreland during the occurrence of a mountain lee wave (see explanations in text)

które wzbudzają najintensywniejszy ruch falowy. Na ogół po starcie z lotniska zespół samolot-szybowiec wykonuje lot ku południowi, gdzie następuje wyczepienie szybowca w warunkach umiarkowanego wznoszenia falowego. Następnie pilot penetruje najbliższą część pola II w celu uzyskania możliwie dużej wysokości. Kolejnym manewrem jest skierowanie szybowca ku zachodowi (nad Pasmo Magurskie) lub ku wschodowi (nad Pasmo Bukowicy). Dogodne warunki do 
osiągnięcia dużej wysokości lotu zwykle występują w okolicy Zbiornika Sieniawskiego oraz miejscowości Bukowsko (rzędu 4000-4500 m nad poziomem lotniska). Po wykonaniu próby osiągnięcia maksymalnej wysokości lotu pilot kieruje szybowiec do miejsca rozpoczęcia lotu swobodnego, skąd następuje powrót na lotnisko. Przykładem lotu wahadłowego może być lot J. Gruszeckiego wykonany 8 listopada $1994 \mathrm{r}$.

Lot ku wschodowi w polu II stwarza możliwość przejścia z fali nad Beskidem Niskim na falę nad Bieszczadami, a tym samym osiągnięcie jeszcze większej wysokości lotu. Dotychczas w trakcie lotu falowego nad Beskidem Niskim nigdy nie miało miejsca uzyskanie przewyższenia $\geq 5000 \mathrm{~m}$, jednak $\mathrm{w}$ sprzyjających warunkach meteorologicznych i przy przejściu w decydującym momencie lotu na falę nad Bieszczadami, taki wyczyn wydaje się możliwy. Potwierdzeniem może być lot M. Markiewicza wykonany 8 listopada 1994 r. Znajdując się około 3 km w kierunku SE od Bukowska, na wysokości 4500 m nad poziomem lotniska, pilot ten dostrzegł nad Zbiornikiem Solińskim chmury Ac len o podstawie na około $5000 \mathrm{~m}$.

Pole falowe III znajduje się najbliżej lotniska w Krośnie i jest związane z wtórnym zafalowaniem w atmosferze, będącym konsekwencją fali pierwszej oraz drugiej. Jego charakterystyczną cechą jest zmienne położenie.

Do powstania pola III może dochodzić wyłącznie w trakcie fali orograficznej o umiarkowanej lub dużej intensywności. W pierwszym przypadku pole jest usytuowane na południe od lotniska, na linii Szczepańcowa-Łężany (pole IIIa), natomiast w drugim przypadku - na północ od lotniska, na linii Jaszczew-Zawodzie-Iskrzynia-Jasionów (pole IIIb). Potwierdzają to dane empiryczne pilotów (m.in. Z. Kwiatka i J. Gruszeckiego uzyskane w trakcie lotów odpowiednio 28.11.1959 i 25.08.1987).

Zmienność położenia pola III wynika ze zmiennej intensywności fali orograficznej. Zależnie od panujących warunków atmosferycznych (głównie prędkości wiatru), długość fal zmienia się, co powoduje przemieszczanie się pola. Wzrost prędkości wiatru powoduje zwiększenie się długości fal, a tym samym przesunięcie pola ku północy, natomiast spadek prędkości wiatru - zmniejszenie się długości fal i ruch pola ku południowi.

Pole III jest wykorzystywane w trakcie lotów rzadziej niż II, ponieważ mniejsza jest tu prędkość prądów wstępujących: falowych (średnio $2 \mathrm{~m} \cdot \mathrm{s}^{-1}$, maksymalnie $4 \mathrm{~m} \cdot \mathrm{s}^{-1}$ ) i rotorowych (średnio $2 \mathrm{~m} \cdot \mathrm{s}^{-1}$ ). Duża jest zaś mobilność pola, utrudniająca utrzymanie szybowca w jego obrębie.

Pole III najczęściej wykorzystuje się do lotów czasowych, a tylko sporadycznie do lotów wysokościowych. Jest także miejscem szkolenia pilotów niemających doświadczenia w lotach falowych. Sprzyjają temu zarówno względy bezpieczeństwa, jak i aspekty finansowe (widoczność lotniska w trakcie lotu, mała od niego odległość, krótki, a tym samym tani lot zespołu samolot-szybowiec do pola falowego). Dla doświadczonych pilotów lot w polu III stanowi często 
etap pośredni lotu falowego, w którym po wzniesieniu szybowca na odpowiednio dużą wysokość, wykonywany jest przeskok do pola II (np. lot J. Gruszeckiego 26 października 1984 r.).

Pole falowe IV. Obecność pola falowego IV w okolicy Krosna nie została dotychczas udokumentowana, jednak bazując na materiałach źródłowych Aeroklubu Podkarpackiego jego występowanie wydaje się prawdopodobne. Dowodem na obecność pola może być obserwacja chmur soczewkowatych nad okolicami Strzyżowa na wysokości około 4000 m, dokonana przez M. Markiewicza 8 listopada 1994 r. w trakcie lotu falowego nad Beskidem Niskim.

Geneza domniemanego pola IV nie jest znana, jednak można przypuszczać, że jest ono uwarunkowane falą generowaną nad Beskidem Niskim lub Pogórzem Strzyżowskim. Możliwa jest również sytuacja, w której wspomniane przeszkody jednocześnie oddziałują na powstawanie pola IV: pasma Beskidu Niskiego oraz Pogórza są do siebie w przybliżeniu równoległe, ruch falowy wzbudzany nad pierwszym z nich może nakładać się na taki sam ruch wywoływany przez drugą przeszkodę. Interferencja fal mogłaby doprowadzić do wzmocnienia lub wygaszenia nad Pogórzem fali generowanej w Beskidzie Niskim.

Potwierdzenie wzmocnienia fali nad Pogórzem na skutek interferencji miałoby duże znaczenie dla Aeroklubu Podkarpackiego. Zwiększenie prędkości wstępujących prądów falowych stwarzałoby możliwość wykonywania tam lotów (domniemane pole IV). Pole to mogłoby także być ważne w przypadku lotów w kierunku północnym - po starcie z lotniska i wzniesieniu szybowca na odpowiednio dużą wysokość w polu I, można by podjąć próbę lotu ku północy w celu przebycia możliwie długiej trasy. Realizacji tego zadania sprzyjałby zarówno lot zgodnie z kierunkiem wiatru, jak i sposobność wykorzystywania prądów wstępujących w polach falowych (kolejno od I do IV). W zależności od warunków atmosferycznych nad Beskidem Niskim oraz Pogórzem (intensywność fali), a także na północ od nich (kierunek i prędkość wiatru, występowanie wstępujących prądów konwekcyjnych), możliwy byłby lot z Krosna do lotnisk w Rzeszowie $(52 \mathrm{~km})$, w Mielcu $(73 \mathrm{~km})$, w Stalowej Woli $(107 \mathrm{~km})$ lub jeszcze dłuższych lotów docelowych lub otwartych.

\section{Ocena właściwości fali orograficznej w Beskidzie Niskim dla szybownictwa}

Fala orograficzna w Beskidzie Niskim znacząco kształtuje warunki prowadzenia aktywności szybowcowej, wydatnie rozszerzając czasowe i przestrzenne ramy możliwości wykonywania lotów nad tym pasmem górskim i jego przedpolem.

Przy spełnieniu odpowiednich warunków, do powstawania fali w Beskidzie Niskim może dochodzić w ciągu całego roku, tym samym zjawisko wydłuża potencjalny okres lotów szybowcowych. Informacja ta odnosi się zwłaszcza 
do półrocza chłodnego i nocnej części doby, kiedy w atmosferze występują warunki korzystne do rozwoju fal grawitacyjnych, natomiast niekorzystne dla konwekcji.

Fala stwarza warunki sprzyjające aktywności szybowcowej w większym wycinku atmosfery niż konwekcja. Prądy falowe są uporządkowane w przestrzeni w jednostki o dużej powierzchni, natomiast prądy konwekcyjne mają charakter lokalny i występują na małym obszarze. Różnice między tymi prądami wyrażają się także możliwością ich wykorzystania w trakcie lotów wysokościowych. Mimo że prądy falowe i konwekcyjne mogą występować w przybliżeniu do tej samej wysokości - równej wysokości górnej granicy troposfery - znaczenie tych drugich dla lotów jest mniejsze. Przyczyną jest powstawanie w warunkach silnej konwekcji chmur Cumulus congestus i Cumulunimbus, w których wykonywanie lotów szybowcowych jest zabronione przepisami lotniczymi ze względów bezpieczeństwa.

Korzystną dla szybownictwa własnością fali w Beskidzie Niskim, dotychczas jednak niedostatecznie potwierdzoną, jest jej duża częstość. Jeśli okaże się prawdą, loty z wykorzystaniem fali można będzie wykonywać tu częściej niż nad pozostałymi pasmami głównymi Karpat Polskich. Jest to ważne zwłaszcza w kontekście planowanej rozbudowy ośrodka lotniczego w Krośnie i jego szkoleniowego charakteru.

Z kolei negatywną dla szybownictwa cechą fali w Beskidzie Niskim jest jej mała intensywność, ograniczająca wykonywanie lotów wysokościowych. Potwierdzają to materiały źródłowe Aeroklubu Podkarpackiego: wysokość maksymalna w trakcie lotów wynosiła najczęściej $2500 \div 4000$ m nad poziomem lotniska. Mały jest także zasięg poziomy fali, co zmusza do wykonywania lotów w małej odległości od pasma górskiego.

Częste zmiany intensywności fali w Beskidzie Niskim i uwarunkowane nimi zjawiska (niestabilne położenie pól falowych i rotorów, zmienna prędkość prądów falowych i rotorowych, powstawanie i zanikanie chmur Ac len i Cu rot) powodują duże zróżnicowanie warunków aktywności szybowcowej w trakcie jej występowania. Skutkiem tego jest trudność w podjęciu decyzji o terminie i miejscu wykonania lotu, a także konieczność prowadzenia przez pilotów ciągłych obserwacji i wykonywania manewrów w celu dostosowania lotu do aktualnych warunków atmosferycznych. Decyzję o terminie lotu utrudnia także możliwość występowania zjawiska o krótkim czasie trwania.

Przedpole Beskidu Niskiego jest korzystnym obszarem do lotów falowych w przypadku zmiany kierunku wiatru z S na SW lub na odwrót. Zmiana ta nie powoduje pogorszenia warunków lotu, ponieważ pilot może skierować szybowiec nad wschodnią lub zachodnią część Beskidu, gdzie może dojść do wzbudzenia intensywniejszego ruchu falowego. Lokalizację lotniska w Krośnie - na przedpolu środkowej części Beskidu - można w tym kontekście uznać za odpowiednią. 
Dzięki niskiemu położeniu podstawy prądów falowych na przedpolu Beskidu Niskiego koszt organizacji lotów jest tu mniejszy niż nad pozostałymi pasmami głównymi Karpat Polskich (m.in. krótszy, a tym samym tańszy lot zespołu samolot-szybowiec do prądów wstępujących, możliwość częstszego zastosowania startu szybowców za pomocą wyciągarki oraz większy zakres wysokości, w której pilot nie ma obowiązku stosowania aparatury tlenowej). Własność ta wraz z domniemaną dużą częstością zjawiska sprawia, że przedpole Beskidu Niskiego stanowi korzystne miejsce do rozpoczynania lotu falowego. Po osiągnięciu odpowiednio dużej wysokości pilot może skierować szybowiec nad wyższe pasma Karpat Polskich, z intensywniejszym ruchem falowym. Położenie Beskidu Niskiego w oddaleniu od wschodniej i zachodniej granicy państwa sprzyja wykonywaniu takich operacji lotniczych.

Zagrożeniem dla lotów wykonywanych z Krosna związanym z falą orograficzną jest możliwość pojawienia się zstępujących prądów rotorowych nad lotniskiem, zwłaszcza nad obszarem, w którym odbywa się start i lądowanie szybowców.

Mała intensywność cyrkulacji powietrza w rotorach na przedpolu Beskidu Niskiego zwiększa bezpieczeństwo lotu w warstwie podfalowej (m.in. mniejsze zmiany siły nośnej w trakcie przelotu przez rotor oraz mniejsze prawdopodobieństwo zerwania liny holowniczej między samolotem i szybowcem). Jednocześnie mała prędkość wstępujących prądów rotorowych sprawia, że możliwość ich wykorzystywania w trakcie lotów jest ograniczona.

Rzadkie występowanie chmur soczewkowatych i rotorowych w trakcie fali w Beskidzie Niskim jest niekorzystne dla szybownictwa. Chmury te umożliwiają bowiem orientację w wycinku atmosfery objętym ruchem falowym. Obecność chmur Ac len zdradza położenie grzbietów fal, natomiast chmur Cu fra - rotorów. Pilot po dostrzeżeniu tych chmur może określić położenie prądów wstępujących i zstępujących (kolejno po ich dowietrznej i zawietrznej stronie). Ponieważ rotory występują zawsze pod tymi samymi elementami fal (grzbietami), na podstawie chmur $\mathrm{Cu}$ fra możliwe jest szybkie i pewne zlokalizowanie prądów falowych, nawet mimo braku chmur Ac len. Analogicznie, korzystając wyłącznie z chmur Ac len, można określić położenie rotorów.

Niekorzystna jest obecność chmur piętra dolnego w trakcie lotów falowych, ponieważ ograniczają one widzialność terenu, a tym samym orientację. Dotyczy to szczególnie południowej części Beskidu Dukielskiego, gdzie pasma górskie są niższe o $100 \div 200 \mathrm{~m}$ w porównaniu do pasm położonych dalej na północ. W trakcie adwekcji powietrza z południa chmury te gromadzą się zwłaszcza w okolicy Przełęczy Dukielskiej. 


\section{Wnioski}

Własności fali orograficznej są kształtowane pod wpływem czynników orograficznych i meteorologicznych. Pierwsze z nich decydują o warunkach brzegowych występowania zjawiska (kierunek i minimalna prędkość przepływu powietrza niezbędne do wzbudzenia ruchu falowego, maksymalny zasięg pionowy), te drugie zaś odpowiadają za zróżnicowanie własności fali w obrębie zakresu uwarunkowanego rzeźbą terenu.

Podobieństwo fali w Beskidzie Niskim i nad pozostałymi pasmami głównymi Karpat Polskich jest związane głównie z czynnikami meteorologicznymi, przede wszystkim stanem równowagi atmosfery i warunkami cyrkulacyjnymi, i wyraża się:

1) prawdopodobnie zbliżonym przebiegiem rocznym (maksimum późną jesienią, minimum późną wiosną i latem);

2) zbliżonymi uwarunkowaniami cyrkulacyjnymi (adwekcja powietrza z południa i południowego zachodu, sytuacje raczej cyklonalne niż antycyklonalne).

Różnice własności fali w Beskidzie Niskim oraz nad pozostałymi pasmami głównymi Karpat Polskich wynikają głównie z czynników orograficznych (wysokości i orientacji pasm górskich). Falę Beskidu Niskiego w porównaniu do innych fal karpackich (zwłaszcza tatrzańskiej) charakteryzuje:

1) mniejsza minimalna prędkość wiatru wywołującego zjawisko (około $7 \mathrm{~m} \cdot \mathrm{s}^{-1}$ );

2) prawdopodobnie większa częstość (hipoteza wymagająca potwierdzenia);

3) mniejsza intensywność i słabszy rozwój cyrkulacji rotorowej;

4) mniejszy zasięg pionowy (4000-8000 m) oraz poziomy $(<50 \mathrm{~km})$;

5) niższe położenie podstawy pól falowych (średnio około $700 \mathrm{~m} \mathrm{npm}$.);

6) prawdopodobnie rzadsze występowanie silnie rozwiniętego zachmurzenia falowego i rotorowego oraz częstsze pojawianie się fali bez tego zachmurzenia;

7) rzadsze występowanie zachmurzenia orograficznego w piętrze dolnym w przypadku wysoko położonego poziomu kondensacji pary wodnej;

8) częstsze występowanie zachmurzenia orograficznego w piętrze dolnym po stronie zawietrznej Beskidu Niskiego w przypadku nisko położonego poziomu kondensacji pary wodnej;

9) duże zniekształcenie prostoliniowego przebiegu pól falowych (zakrzywienie ich ku południowi w części wschodniej);

10) korzystne położenie w granicach polskiej przestrzeni powietrznej, umożliwiające wykonywanie lotów falowych w kierunku zarówno wschodnim, jak i zachodnim (w przeciwieństwie do fali w Beskidzie Śląskim i Żywieckim, a zwłaszcza w Bieszczadach - granica zewnętrzna Unii Europejskiej). 


\section{Piśmiennictwo}

Dokumentacja szybowcowych akcji lotów falowych, Aeroklub Podkarpacki, Krosno (materiały źródłowe z lat 1957-1994).

Ferguson N. A., 2001, In the Lee of Giants, AOPA Pilot Magazine, 44, 12, s. 78-85.

Instrukcja lotów szybowcowych, Górska Szkoła Szybowcowa Aeroklubu Polskiego „Żar”, Międzybrodzie Żywieckie.

Kondracki J., 2002, Geografia regionalna Polski, Wydawnictwo Naukowe PWN, Warszawa.

Lewińska J., 1958, Wiatry ryterskie i rymanowskie, Przegląd Geofizyczny, 3 (11), 1, s. $17-26$.

Mozdyniewicz W., 1976, Loty falowe, seria Szkolenie szybowcowe, Wydawnictwa Komunikacji i Łączności, Warszawa.

Niedźwiedź T., 2001, Kalendarz typów cyrkulacji w Polsce potudniowej w okresie 1.09.187331.12.2000, zbiór komputerowy dostępny na: http://klimat.wnoz.us.edu.pl, (1.03.2011 r.)

Ostrowski M., 1999, Meteorologia dla lotnictwa sportowego, Aeroklub Polski, Warszawa.

Parczewski W., 1953, Meteorologia szybowcowa, Wydawnictwo Ligi Lotniczej, Warszawa.

-, 1959, O przeptywie powietrza przez wyniosłości terenowe ze szczególnym uwzględnieniem Tatr, Wiadomości Służby Hydrologicznej i Meteorologicznej, 7, 5.

Schiele T., 1979, Wspinaczki po chmurach, Iskry, Warszawa.

Schmidt M.T., 1982, Meteorologia dla potrzeb szybownictwa, seria Szkolenie szybowcowe, Wydawnictwa Komunikacji i Łączności, Warszawa.

-, 2002, Warunki meteorologiczne występowania tatrzańskiej fali orograficznej, UMCS, Lublin, maszynopis.

Świst T., 2000, Przygotowanie teoretyczne pilotów szybowcowych do lotów na fali tatrzańskiej, Ośrodek Szybowcowych Lotów Falowych Aeroklubu Polskiego, Nowy Targ.

Urbanek R., 1993, Historia szybownictwa na Podkarpaciu, Wyższa Szkoła Pedagogiczna, Rzeszów, maszynopis.

Wyszogrodzki A., 2001, Wptyw procesów falowych w atmosferze na strukturę planetarnej warstwy granicznej, Instytut Geofizyki, Warszawa, maszynopis.

[Wpłynęło: styczeń; poprawiono: maj 2011 r.]

\section{JAKUB SZMYD}

ON CERTAIN CASES OF A MOUNTAIN LEE WAVE IN THE BESKID NISKI MTS. AND ITS SIGNIFICANCE TO GLIDING

A mountain lee wave is a stationary gravity wave excited in the flow of air over a high-terrain obstacle (Parczewski, 1953, Schmidt, 1982). The phenomenon can be compared, by analogy of formation mechanism, with the wave motion of water in a river, behind the step of the bed rock. A lee wave has an important role to play as regards gliding, since ascending wave currents allow record-breaking flights to be made in terms of both length and height. 
The aim of the paper is to characterize the lee wave in the Beskid Niski Mts., and especially to determine the differences between properties of the phenomenon in the Beskid Niski Mts. and in the other major mountain ranges of the Polish Carpathians. The practical purpose of the study is to recognize the importance of the phenomenon to gliding activity near the planned air training centre in Krosno city.

On the basis of Podkarpacki Aeroclub documentation of mountain lee wave gliding campaigns, it has been found that the phenomenon occurs most often in the cold half of the year (particularly in November), mostly with southerly or south-westerly air advection, and more cyclonic than anticyclonic cases of atmospheric circulation. The minimum wind speed required for a lee wave to be generated in the Beskid Niski Mts. is $7 \mathrm{~m} \cdot \mathrm{s}^{-1}$, not necessarily in conditions of stable atmospheric circulation.

On the basis of theoretical considerations, it was hypothesised that the Beskid Niski represent the mountain range within the Polish Carpathians in which the lee wave occurs most often, albeit at the lowest intensity and with the smallest maximal vertical and horizontal range (4000-8000 $\mathrm{m}$ and $<50 \mathrm{~km}$ ) in comparison with the other ranges. The typical features of the lee wave in the Beskid Niski Mts. are: low altitude of the wave current base (at an average elevation over $700 \mathrm{~m}$ a.s.l.), with rarely appearing strongly developed wave and rotor clouds, as well as frequent cases of cloudless phenomenon.

Beskid Niski's lee wave occupies a favorable position within Polish airspace, enabling glider flights to be mounted to both the east and the west, in opposition to the lee wave in the Beskid Śląski, Beskid Żywiecki, and especially the Bieszczady Mts. (in which the external border of the European Union is reached). During a glider flight on a lee wave in the Beskid Niski Mts., it is possible to obtain heights $\geq 3000 \mathrm{~m}$.

This paper advances a hypothesis regarding a strengthening of the Beskid Niski mountain lee wave above the Central Beskidy Foothills, as a result of wave interference induced by both barriers mentioned. The paper also contains descriptions of fields with ascending wave air currents in the eastern part of the Beskid Niski Mts., as well as a list of glider flights on lee waves participated in by the Podkarpacki Aeroclub. 
Wykaz lotów szybowcowych wykonanych na fali orograficznej w Beskidzie Niskim, 1957-1994

List of glider flights on a mountain lee wave in the Beskid Niski, 1957-1994

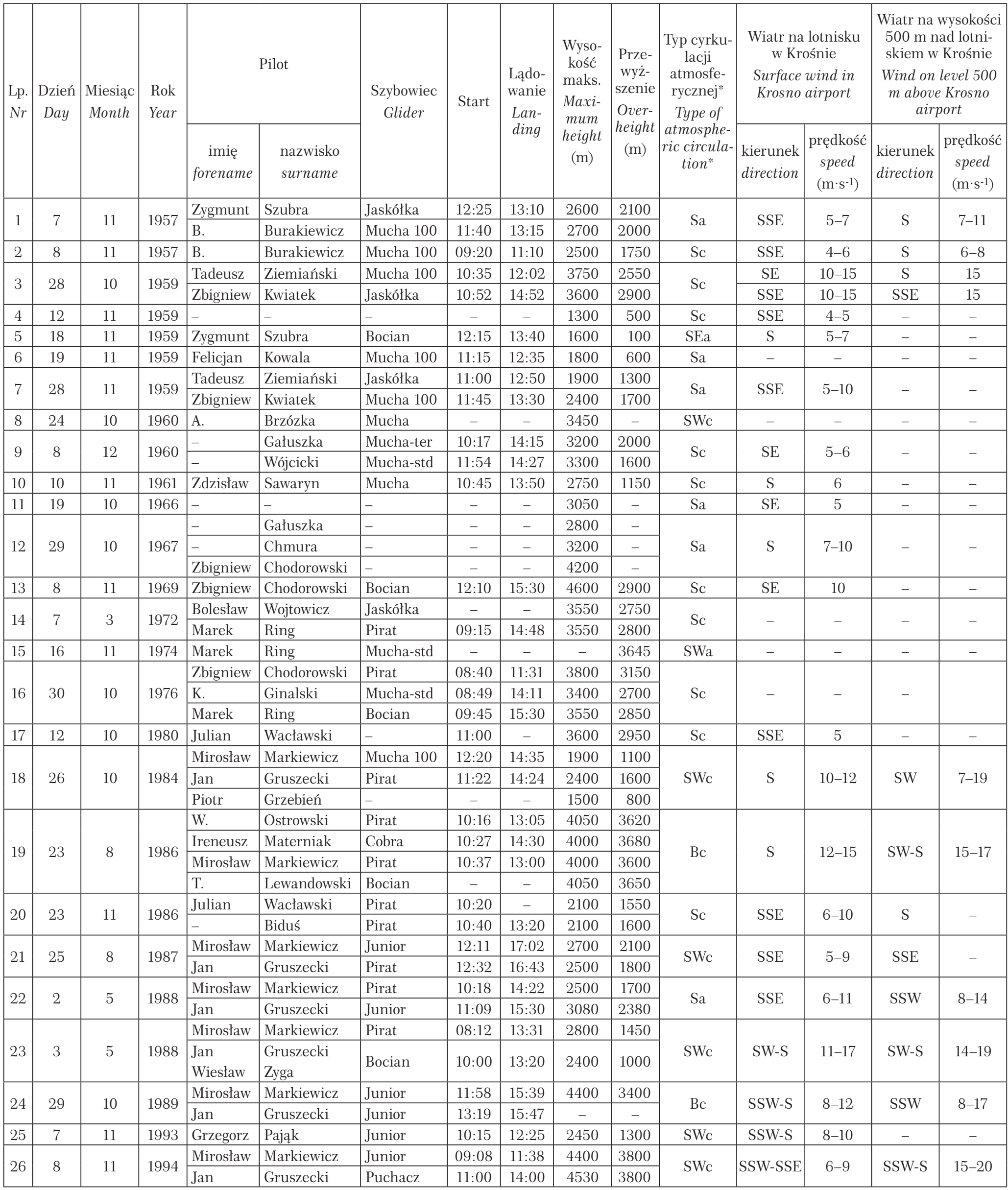

* według/based on: Niedźwiedź (2001).

Źródło danych: Dokumentacja ... (dane z lat 1957-1994).

Data source: Podkarpacki Aeroclub documentation of mountain lee wave gliding campaigns (data from years 1957-1994). 